\title{
Beta-3 Receptor Agonists
}

\section{Erasmus Bachus ${ }^{1}$, Piotr Ponikowski ${ }^{2}$}

1. Lund University, Sweden

2. Head of the Department of Heart Diseases, Wroclaw Medical University and Head of the Cardiology Department at the Center for Heart Diseases at 4th Military Hospital, Wroclaw, Poland

\section{Corresponding author:}

Prof Piotr Ponikowski, Head of the Department of Heart Diseases,

Wroclaw Medical University and Head of the Cardiology Department at the Center for Heart Diseases at 4th Military Hospital, Wroclaw, Poland.

Email: piotrponikowski@4wsk.pl

\begin{abstract}
Beta-3 adrenergic receptors ( $\beta 3-\mathrm{AR})$ have a more widespread tissue distribution in the human body as compared to beta1- and beta2 ( $\beta 1 / 2)$-adrenergic receptors, including in the bladder, brain, adipose tissue and cardiovascular system. Thus, $\beta 3-\mathrm{AR}$ are potential drug targets for a wide range of therapeutic areas, both cardiovascular and non-cardiovascular including overactive bladder (OAB), depression, metabolic syndrome, obesity and heart failure (HF). $\beta 3-A R$ agonists that are selective to the $\beta 3-A R$ include CL 316,243, amibegron (SR58611A), mirabegron (YM-178) and vibegron (RVT-901). However, in HF, study results regarding a possible inotropic effect of $\beta 3-A R$ agonists remain equivocal and some authors report a negative inotropic effect in HF and $\beta 3-A R$ antagonists are also under study.
\end{abstract}

Keywords: heart failure, beta-3 adrenergic receptors,; mirabegron

Citation: Bachus E, Ponikowski P. Beta-3 Receptor Agonists. International Cardiovascular Forum Journal. 2019;18:15-18. DOI: 10.17987/icfj.v18i0.615

\section{Introduction}

Beta-3 adrenergic receptors ( $\beta 3-\mathrm{AR})$ belong to the superfamily of G protein-coupled receptors and show a more widespread tissue distribution in the human body as compared to beta1- and beta2 $(\beta 1 / 2)$-adrenergic receptors. For example $\beta 3-A R$ have been described to be present in the bladder, brain, adipose tissue and cardiovascular system, among other tissues. Thus, $\beta 3-A R$ are potential drug targets for a wide range of therapeutic areas, both cardiovascular and non-cardiovascular including overactive bladder (OAB), depression, metabolic syndrome, obesity and heart failure (HF).[1]

\section{Selective beta-3 adrenergic agonists}

$\beta 3-A R$ agonists that are selective to the $\beta 3-A R$ include $C L$ 316,243, amibegron (SR58611A), mirabegron (YM-178) and vibegron (RVT-901). These $\beta 3-A R$ agonists have different profiles. For example, CL 316,243 has anti-obesity and antidiabetic properties and amibegron has antidepressant effects in animal models. Mirabegron is approved for the treatment of $\mathrm{OAB}$ syndrome, and vibegron is currently under development in human clinical trials also for the treatment of that condition. Newer $\beta 3$-selective compounds showing interesting profiles as potential drugs for the treatment of obesity and non-insulindependent diabetes have recently been reported.[1]

\section{Cardiovascular/metabolic properties and therapeutic concepts}

Adipose tissue and diabetes. $\beta 3-A R$ mediate lipolysis in white adipose tissue and thermogenesis in brown adipose tissue.[2-4] The presence of the Arg64 allele in the first intracellular loop of the $\beta 3-A R$ gene may predispose subjects to abdominal obesity, which may in turn predispose them to insulin resistance and the earlier onset of type 2 diabetes mellitus.[5] B3-AR agonists appear to be of significance not only for the treatment of obesity, but also in terms of the risks of cardiovascular disorders related to visceral obesity, the form of obesity, which is more directly linked to augmented $\beta 3-A R$ activity.[6,7]

Vascular smooth muscles. $\beta 3-A R$ produce the sustained peripheral vasodilation, which is predominant in skin and fat.[8,9] Studies have shown that the relaxation of rat thoracic aorta was caused by selective $\beta 3-A R$ agonists.[10-13] A $\beta 3-A R-m e d i a t e d$ vasorelaxation was also observed in the canine pulmonary artery. [14] The presence of $\beta 3-A R$ has also been reported in veins of rats.[15] Also in rats, it was demonstrated that $\beta 3-A R$ stimulation causes a vasodilation of microvessels in the islets of Langerhans. $[7,16]$

Endothelium. In human vessels, $\beta 3-A R$ vasorelaxation was found to be mediated partly through the production of nitric oxide (NO) [17], which may be caused by the functional coupling of $\beta 3-A R$ agonists to NO production.[7,18,19] 
Cardiac effects. $\beta 3-A R$ stimulation of the human cardiac muscle, in contrast with $\beta 1-A R$ and $\beta 2-A R$ stimulation, results in a profound dose-dependent negative inotropic effect, which has been shown in different animal models. These findings may suggest that $\beta 3-A R$ may participate in the pathophysiology of HF.[20] Functional $\beta 3-A R$ stimulation, which occurs in the normal left ventricle, causes a direct inhibition on calcium (Ca2+) channels and produces a negative inotropic action.[21] It has been found that $\beta 3-A R$ activation inhibits the L-type Ca2+channel in both normal and HF rat myocytes. In HF, $\beta 3-A R$ stimulation-induced inhibition of $\mathrm{Ca} 2+-$-channels was enhanced, which was responsible for the reduced inotropic response[7,22], and an increased activity of the sympathetic nervous system led to the downregulation of cardiac $\beta 1$ - and $\beta 2-A R$ in HF.[20] Reduced $\beta 1$ - and $\beta 2-A R$ expression leads to a decrease in the contractile response to $\beta$-AR agonists.[23] Contrary to $\beta 1$ - and $\beta 2-A R$, the abundance of the negatively inotropic $\beta 3-A R$ increases in the failing myocardium.[18] $\beta 3-A R$ lack the phosphorylation sites for cAMP-dependent protein kinase or $\beta-A R$ kinase[23], and thus may not be downregulated in HF. Accordingly, the high adrenoceptor tone during HF may alter the cardiac contractile activity as a result of unmasked $\beta 3-A R$ stimulation in the presence of reduced $\beta 1$ - and $\beta 2-A R$.[24] Overstimulation of the relatively desensitization-resistant $\beta 3-A R[25]$ after increased sympathetic tone and norepinephrine release in the setting of $\mathrm{HF}$ in humans may further decrease cardiac inotropy.[18] The levels of $\beta 3-A R$ mRNA and proteins show an increase in the failing heart compared with the nonfailing heart. If the levels of $\beta 3-A R$ are too high, they might contribute to the loss of cardiac function and be the foundation of the functional degradation in HF.[26] These study results may suggest the treatment options with specific antagonists of the human cardiac $\beta 3-A R$ for correcting the disordered adrenergic regulation of the failing heart.

Contrary to the aforementioned evidence, it has been reported that increased intracellular myocyte sodium $(\mathrm{Na}+)$ levels represent a key adverse pathophysiological feature of $\mathrm{HF}$, and that the $\beta 3-$ AR mediates the stimulation of the only export route for $\mathrm{Na}+$, the sodium-potassium ( $\mathrm{Na}+-\mathrm{K}+$ )-pump. The upregulation of the $\beta 3-$ AR may thereby represent a useful compensatory mechanism. Thus $\beta 3-A R$ agonists may be a potential therapeutic option for the treatment of HF.[27]

However, study results regarding the inotropic effect of $\beta 3-A R$ agonists remain equivocal. As mentioned above, some authors conclude that there is a negative inotropic effect (mainly in HF models)[21,28], whereas others do not agree.[29,30] The reasons for this discrepancy probably include the type and dose of the agonist used (with high doses of non-specific agonists producing opposing positive inotropic effects) and the control systems mediating for reflex orthosympathetic reactions leading to intense peripheral vasodilatation.[29]

Data from experimental models (summarised in table 1; but by no means exhaustive) have shown promising effects on cardiac function in HF and relevant co-morbidities.[30] These include beneficial effects on oxidative stress[31], augmentation in left ventricular contractility[32], diabetes-induced cardiac dysfunction[33], cardiac arrhythmia control after myocardial infarction[34], pulmonary hypertension[35-37] and erectile function (ED).[38]

\begin{tabular}{|c|c|c|c|}
\hline $\begin{array}{l}\text { Effect/medical } \\
\text { condition }\end{array}$ & $\begin{array}{l}\text { Organ/ } \\
\text { tissue }\end{array}$ & Species & Reference \\
\hline Heart failure & Heart & Sheep & $\begin{array}{l}\text { Bundgaard et } \\
\text { al. } 2010 \text { [30] }\end{array}$ \\
\hline $\begin{array}{l}\text { Chronic heart } \\
\text { failure }\end{array}$ & Heart & Rat & $\begin{array}{l}\text { Kong et al. } \\
2010 \text { [31] }\end{array}$ \\
\hline $\begin{array}{l}\text { Cardiac } \\
\text { contractility }\end{array}$ & Heart & $\begin{array}{l}\text { Mice/human } \\
\text { (transgenic) }\end{array}$ & $\begin{array}{l}\text { Kohout et al. } \\
2001 \text { [32] }\end{array}$ \\
\hline Diabetes & Heart & Rat & $\begin{array}{l}\text { Dinçer et al. } \\
2001 \text { [33] }\end{array}$ \\
\hline $\begin{array}{l}\text { Ventricular } \\
\text { tachycardia }\end{array}$ & Heart & Dog & $\begin{array}{l}\text { Zhou et al. } \\
2008 \text { [34] }\end{array}$ \\
\hline $\begin{array}{l}\text { Pulmonary } \\
\text { hypertension }\end{array}$ & $\begin{array}{l}\text { Pulmonary } \\
\text { artery }\end{array}$ & Dog & $\begin{array}{l}\text { Tagaya et al. } \\
1999 \text { [35] }\end{array}$ \\
\hline $\begin{array}{l}\text { Pulmonary } \\
\text { hypertension }\end{array}$ & Lung & Rat & $\begin{array}{l}\text { Dumas et al. } \\
1998 \text { [36] }\end{array}$ \\
\hline $\begin{array}{l}\text { Pulmonary } \\
\text { hypertension }\end{array}$ & $\begin{array}{l}\text { Pulmonary } \\
\text { artery }\end{array}$ & Pig & $\begin{array}{l}\text { García-Álvarez } \\
\text { et al. } 2016 \text { [37] }\end{array}$ \\
\hline $\begin{array}{l}\text { Erectile } \\
\text { dysfunction }\end{array}$ & $\begin{array}{l}\text { Corpus } \\
\text { cavernosum/ } \\
\text { penile artery }\end{array}$ & Human & $\begin{array}{l}\text { Mitidieri et al. } \\
2017 \text { [38] }\end{array}$ \\
\hline $\begin{array}{l}\text { Cardiac } \\
\text { remodelling }\end{array}$ & $\begin{array}{l}\text { Cardiac } \\
\text { myocyte }\end{array}$ & $\begin{array}{l}\text { Mice/human } \\
\text { (transgenic) }\end{array}$ & $\begin{array}{l}\text { Belge et al. } \\
2014 \text { [39] }\end{array}$ \\
\hline $\begin{array}{l}\text { Heart failure/ } \\
\text { cardiac } \\
\text { remodelling }\end{array}$ & Heart & $\begin{array}{l}\text { Mice/knockout } \\
\text { mice }\end{array}$ & $\begin{array}{l}\text { Niu et al. } \\
2012 \text { [41] }\end{array}$ \\
\hline
\end{tabular}

Many of these direct and indirect mechanisms combine to modulate chronic myocardial remodelling. One important aspect is cardiac myocyte hypertrophy. It has been shown that $\beta 3-\mathrm{AR}$ attenuate cardiac myocyte hypertrophy in response to a continuous or repetitive infusion of isoproterenol or angiotensin II and a reduction of hypertrophy in response to different $\beta 3-A R$ agonists. This anti-hypertrophic effect of $\beta 3-A R$ was NO-dependent. $\beta 3-A R$ expression also greatly reduced myocardial interstitial fibrosis due to isoproterenol and angiotensin II infusions.[40] Similar protective effects of $\beta 3-A R$ were reported with preferential $\beta 3-A R$ agonists in mice exposed to trans-aortic constriction, with the subsequent decreased hypertrophy and preserved LV function.[41]

Protective effects of $\beta 3-A R$ agonists at the myocardial level are probably reinforced from indirect effects in peripheral cells/ tissues, i.e. through the coronary vasodilatation via $\beta 3-A R-$ induced endothelial dependent relaxation, as well as the paracrine release of $\mathrm{NO}$ and its effects to improve LV relaxation. Moreover, the antioxidant effects of $\beta 3-A R$ signalling may preserve the endothelium of microvasculature from oxidative activation and the ensuing recruitment of monocytes initiating subendothelial inflammation at the core of sustained endothelial dysfunction. Whether this might prevent from chronic development of vascular atherosclerosis or chronic development of diastolic dysfunction initiating HFpEF[42] has yet to be tested in trials with interventions and long follow-up.[40] 


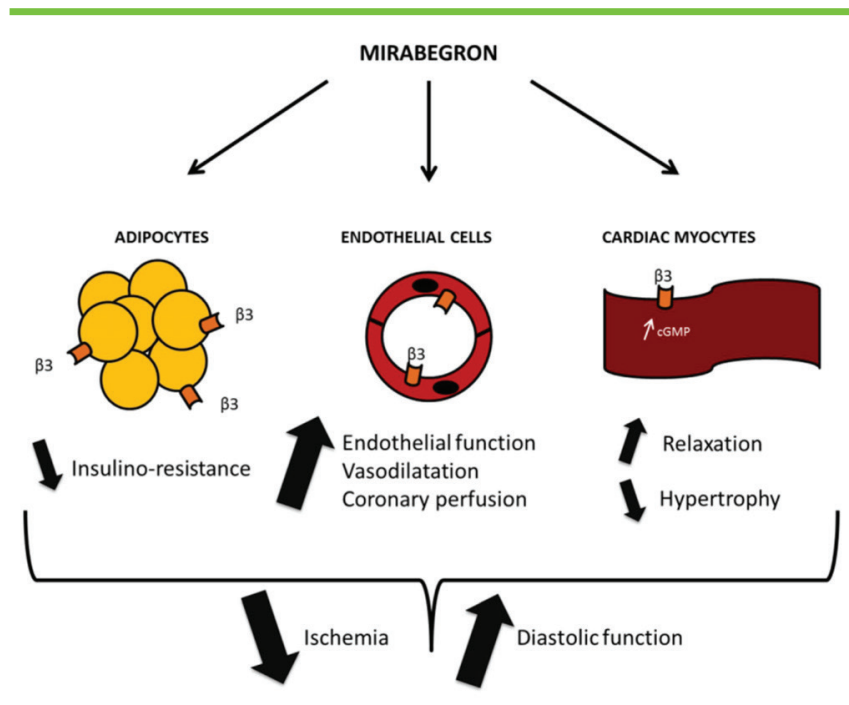

Figure 1. Targets for the therapeutic effect of the $\beta 3$ adrenergic receptor agonist, mirabegron. (reproduced from reference 46 with permission) As a $\beta 3$ adrenergic receptor agonist, mirabegron is expected to activate $\beta 3$ adrenergic receptors in adipocytes (left), resulting in increased adipocyte 'browning', energy expenditure, and peripheral insulin sensitivity; in endothelial cells of the vasculature (centre; including coronary resistance arteries), thereby increasing endothelium-dependent vasodilatation, myocardial perfusion, and paracrine nitric oxidemediated signalling; and in cardiac myocytes (right), resulting in antioxidant and cyclic guanosine monophosphate-mediated protective effects against remodelling and improved relaxation. Altogether, these effects are expected to prevent myocardial ischaemia and improve diastolic function.

After all, it has to be kept in mind that the expression pattern of $\beta 3-A R$ is more restricted than that of other subtypes, particularly in humans, which makes an extrapolation of findings from other species to the human clinical condition difficult, but it may also result in a smaller potential for side effects. The role of $\beta 3-A R$ gene polymorphisms has been insufficiently explored and may differ even between primate species.[43]

\section{Recent and ongoing clinical trials}

The effect of the $\beta 3-A R$ agonist mirabegron on left ventricular ejection fraction (LVEF) was tested in a first-in-man doubleblinded clinical trial: BEAT-HF.[44] The aim was to test the hypothesis of protective effects of $\beta 3-A R$ agonists (study drug: mirabegron) on myocardial function in patients with stable HFrEF, in sinus rhythm and already taking conventional beta blockers. The primary endpoint, an increase in LVEF after 6 months, was not reached, nor was the secondary end-point of exercise capacity. The trial recruited patients with echo-derived LVEF less than $40 \%$, but when assessed in-trial with a CT-derived measure many had LVEF greater than $40 \%$. An exploratory analysis of patients with baseline CT-derived LVEF $<40 \%$ indicated that the $\beta 3 A R$ stimulation by mirabegron increased LVEF compared to placebo. No safety signals were seen and there was no significant effect compared to placebo on HR or BP.[44,45]

The Beta3-LVH trial (rationale recently published[46]) is currently testing the hypothesis that the $\beta 3 A R$ agonist (mirabegron) will ameliorate LV hypertrophy and diastolic function in patients with hypertensive structural heart disease, being at high risk of developing HFpEF. Beta3-LVH is a randomized, placebocontrolled, double-blind, two-armed, multicentre, European, parallel group study. A total of 296 patients will be randomly assigned to receive either mirabegron or placebo over 12 months. Beta3-LVH is the first large-scale clinical trial to evaluate the effects of mirabegron on LVMi and diastolic function in patients with LVH.

Moreover, there are ongoing clinical trials in the fields of pulmonary hypertension, erectile dysfunction and obesity $\beta 3 A R$ agonists. The Beta3 Agonist Treatment in Chronic Pulmonary Hypertension Secondary to Heart Failure (SPHERE-HF) study will evaluate the efficacy and safety of mirabegron in patients with pulmonary hypertension secondary to HF. The Mirabegron For Erectile Dysfunction pilot will evaluate the effect of mirabegron on men with both OAB symptoms and mild to moderate ED. The Efficacy of Pharmacological Stimulation of BAT and WAT in Lean and Obese Young Adults (MiraBAT) is conducted to determine whether the pharmacological stimulation of supraclavicular Brown Adipose Tissue (BAT or "Brown Fat") and subcutaneous White Adipose Tissue (WAT) using mirabegron is as effective in increasing oxidative metabolism in BAT and WAT as is the exposure to cold. The Effects of b3-Adrenergic Receptor Agonists on Brown Adipose Tissue study will test the hypothesis that human BAT can be activated using mirabegron. The efficacy of mirabegron will be compared with cold exposure, as well as to a placebo.

\section{Conclusions}

In conclusion, the pleiotropic protective properties of selective B3-AR agonists make these interesting therapeutic agents, especially in the complex syndrome of HF with all its predisposing cardiometabolic conditions and comorbidities.

\section{Declarations of interest}

The authors declare no conflict of interest.

\section{Acknowledgements}

The authors state that they abide by the authors' responsibilities and ethical publishing guidelines of the International Cardiovascular Forum Journal.[47]

\section{References}

1. Lorca M, Morales-Verdejo C, Vásquez-Velásquez D, Andrades-Lagos J, Campanini-Salinas J, Soto-Delgado J, Recabarren-Gajardo G, Mella J. Structure-Activity Relationships Based on 3D-QSAR CoMFA/CoMSIA and Design of Aryloxypropanol-Amine Agonists with Selectivity for the Human B3-Adrenergic Receptor and Anti-Obesity and Anti-Diabetic Profiles. Molecules. 2018 May 16;23(5).

2. Lönnqvist F, Krief S, Strosberg AD, Nyberg S, Emorine LJ, Arner P. Evidence for a functional beta 3-adrenoceptor in man. $\mathrm{Br} \mathrm{J}$ Pharmacol. 1993 Nov;110(3):929-36.

3. Langin D, Portillo MP, Saulnier-Blache JS, Lafontan M. Coexistence of three beta-adrenoceptor subtypes in white fat cells of various mammalian species. Eur J Pharmacol. 1991 Jul 9;199(3):291-301.

4. Zaagsma J, Nahorski SR. Is the adipocyte beta-adrenoceptor a prototype for the recently cloned atypical 'beta 3-adrenoceptor'? Trends Pharmacol Sci. 1990 Jan;11(1):3-7.

5. Widén E, Lehto M, Kanninen T, Walston J, Shuldiner AR, Groop LC. Association of a polymorphism in the beta 3-adrenergic-receptor gene with features of the insulin resistance syndrome in Finns. N Engl J Med. 1995 Aug 10;333(6):348-51.

6. Arner P. The beta 3-adrenergic receptor - a cause and cure of obesity? N Engl J Med. 1995 Aug 10;333(6):382-3.

7. Bhadada SV, Patel BM, Mehta AA, Goyal RK. $\beta(3)$ Receptors: Role in Cardiometabolic Disorders. Ther Adv Endocrinol Metab. 2011 Apr;2(2):65-79. 
8. Shen YT, Zhang H, Vatner SF. Peripheral vascular effects of beta-3 adrenergic receptor stimulation in conscious dogs. J Pharmacol Exp Ther. 1994 Jan;268(1):466-73.

9. Berlan M, Galitzky J, Bousquet-Melou A, Lafontan M, Montastruc JL. Beta3 adrenoceptor-mediated increase in cutaneous blood flow in the dog. $\mathrm{J}$ Pharmacol Exp Ther. 1994 Mar;268(3):1444-51.

10. Mohell N, Dicker A. The beta-adrenergic radioligand [3H]CGP-12177, generally classified as an antagonist, is a thermogenic agonist in brown adipose tissue. Biochem J. 1989 Jul 15;261(2):401-5.

11. Engel G, Hoyer D, Berthold R, Wagner H. (+/-)[125lodo] cyanopindolol, a new ligand for beta-adrenoceptors: identification and quantitation of subclasses of beta-adrenoceptors in guinea pig. Naunyn Schmiedebergs Arch Pharmacol. 1981;317(4):277-85.

12. Tesfamariam B, Allen GT. Beta 1- and beta 2-adrenoceptor antagonist activities of $\mathrm{ICl}-215001$, a putative beta 3 -adrenoceptor agonist. $\mathrm{Br} J$ Pharmacol. 1994 May;112(1):55-8.

13. Trochu JN, Leblais V, Rautureau $Y$, Bévérelli $F$, Le Marec $H$, Berdeaux A, Gauthier C. Beta 3-adrenoceptor stimulation induces vasorelaxation mediated essentially by endothelium-derived nitric oxide in rat thoracic aorta. Br J Pharmacol. 1999 Sep;128(1):69-76.

14. Tagaya E, Tamaoki J, Takemura H, Isono K, Nagai A. Atypical adrenoceptormediated relaxation of canine pulmonary artery through a cyclic adenosine monophosphate-dependent pathway. Lung. 1999;177(5):321-32.

15. Viard P, Macrez N, Coussin F, Morel JL, Mironneau J. Beta-3 adrenergic stimulation of $\mathrm{L}$-type $\mathrm{Ca}(2+)$ channels in rat portal vein myocytes. $\mathrm{Br} J$ Pharmacol. 2000 Apr;129(7):1497-505.

16. Atef N, Lafontan M, Doublé A, Hélary C, Ktorza A, Pénicaud L. A specific beta 3 -adrenoceptor agonist induces increased pancreatic islet blood flow and insulin secretion in rats. Eur J Pharmacol. 1996 Mar 18;298(3):287-92.

17. Dessy C, Moniotte S, Ghisdal P, Havaux X, Noirhomme P, Balligand JL. Endothelial beta3-adrenoceptors mediate vasorelaxation of human coronary microarteries through nitric oxide and endothelium-dependent hyperpolarization. Circulation. 2004 Aug 24;110(8):948-54.

18. Moniotte S, Kobzik L, Feron O, Trochu JN, Gauthier C, Balligand JL. Upregulation of beta(3)-adrenoceptors and altered contractile response to inotropic amines in human failing myocardium. Circulation. 2001 Mar 27;103(12):1649-55

19. Gauthier, C., Leblais, V., Kobzik, L., Trochu, J.N., Khandoudi, N., Bril, A. et al. (1998) The negative inotropic effect of b3-adrenoceptor stimulation is mediated by activation of a nitric oxide synthase pathway in human ventricle. J Clin Invest 102: 13771384.

20. Brodde OE. Beta-adrenoceptors in cardiac disease. Pharmacol Ther. 1993 Dec;60(3):405-30.

21. Cheng HJ, Zhang ZS, Onishi K, Ukai T, Sane DC, Cheng CP. Upregulation of functional beta(3)-adrenergic receptor in the failing canine myocardium. Circ Res. 2001 Sep 28;89(7):599-606.

22. Zhang ZS, Cheng HJ, Onishi K, Ohte N, Wannenburg T, Cheng CP. Enhanced inhibition of L-type $\mathrm{Ca} 2+$ current by beta3-adrenergic stimulation in failing rat heart. J Pharmacol Exp Ther. 2005 Dec;315(3):1203-11.

23. Strosberg AD. Structure, function, and regulation of adrenergic receptors. Protein Sci. 1993 Aug;2(8):1198-209.

24. Gauthier C, Tavernier G, Charpentier F, Langin D, Le Marec H. Functional beta3-adrenoceptor in the human heart. J Clin Invest. 1996 Jul 15;98(2):556-62.

25. Liggett SB, Freedman NJ, Schwinn DA, Lefkowitz RJ. Structural basis for receptor subtype-specific regulation revealed by a chimeric beta $3 /$ beta 2-adrenergic receptor. Proc Natl Acad Sci U S A. 1993 Apr 15;90(8):3665-9.

26. Kong YH, Li WM, Tian Y. [Effect of beta3-adrenoreceptors agonist on beta3adrenoreceptors expression and myocyte apoptosis in a rat model of heart failure]. Zhongguo Wei Zhong Bing Ji Jiu Yi Xue. 2004 Mar;16(3):142-7.

27. Rasmussen HH, Figtree GA, Krum H, Bundgaard H. The use of beta3adrenergic receptor agonists in the treatment of heart failure. Curr Opin Investig Drugs. 2009 Sep;10(9):955-62.

28. Morimoto A, Hasegawa H, Cheng HJ, Little WC, Cheng CP. Endogenous beta3-adrenoreceptor activation contributes to left ventricular and cardiomyocyte dysfunction in heart failure. Am J Physiol Heart Circ Physio 2004;286:H2425-H2433.

29. Donckier JE, Massart PE, Van Mechelen H, Heyndrickx GR, Gauthier C, Balligand JL. Cardiovascular effects of beta 3-adrenoceptor stimulation in perinephritic hypertension. Eur J Clin Invest 2001;31:681 - 689.

30. Bundgaard H, Liu CC, Garcia A, Hamilton EJ, Huang Y, Chia KK, Hunyor $\mathrm{SN}$, Figtree GA, Rasmussen $\mathrm{HH}$. beta(3) adrenergic stimulation of the cardiac $\mathrm{Na}+-\mathrm{K}+$ pump by reversal of an inhibitory oxidative modification Circulation 2010;122: 2699 - 2708.

31. Kong YH, Zhang Y, Li N, Zhang L, Gao YH, Xue HJ, Li Y, Li WM. [Association between beta3-adrenergic receptor and oxidative stress in chronic hear failure rats]. Zhonghua Xin Xue Guan Bing Za Zhi. 2010 May;38(5):435-9.

32. Kohout TA, Takaoka H, McDonald PH, Perry SJ, Mao L, Lefkowitz RJ, Rockman HA. Augmentation of cardiac contractility mediated by the human beta(3)-adrenergic receptor overexpressed in the hearts of transgenic mice. Circulation. 2001 Nov 13;104(20):2485-91.
33. Dinçer UD, Bidasee KR, Güner S, Tay A, Ozçelikay AT, Altan VM. The effect of diabetes on expression of beta1-, beta2-, and beta3-adrenoreceptors in rat hearts. Diabetes. $2001 \mathrm{Feb} ; 50(2): 455-61$.

34. Zhou S, Tan AY, Paz O, Ogawa M, Chou CC, Hayashi H, Nihei M, Fishbein MC, Chen LS, Lin SF, Chen PS. Antiarrhythmic effects of beta3-adrenergic receptor stimulation in a canine model of ventricular tachycardia. Heart Rhythm. 2008 Feb;5(2):289-97.

35. Tagaya E, Tamaoki J, Takemura H, Isono K, Nagai A. Atypical adrenoceptormediated relaxation of canine pulmonary artery through a cyclic adenosine monophosphate- dependent pathway. Lung 1999;177:321 - 332.

36. Dumas M, Dumas JP, Bardou M, Rochette L, Advenier C, Giudicelli JF. Influence of beta-adrenoceptor agonists on the pulmonary circulation. Effects of a beta3-adrenoceptor antagonist, SR 59230A. Eur J Pharmacol 1998;348:223-228.

37. García-Álvarez A, Pereda D, García-Lunar I, et al. Beta-3 adrenergic agonists reduce pulmonary vascular resistance and improve right ventricular performance in a porcine model of chronic pulmonary hypertension. Basic Res Cardiol. 2016 Jul;111(4):49.

38. Mitidieri E, Tramontano T, Gurgone D, Imbimbo C, Mirone V, Fusco F, Cirino G, d'Emmanuele di Villa Bianca R, Sorrentino R. $\beta(3)$ adrenergic receptor activation relaxes human corpus cavernosum and penile artery through a hydrogen sulfide/cGMP-dependent mechanism. Pharmacol Res. 2017 Oct;124:100-104.

39. Belge C, Hammond J, Dubois-Deruy E, Manoury B, Hamelet J, Beauloye C, Markl A, Pouleur AC, Bertrand L, Esfahani $\mathrm{H}$ et al. Enhanced expression of beta3-adrenoceptors in cardiac myocytes attenuates neurohormoneinduced hypertrophic remodeling through nitric oxide synthase. Circulation 2014;129:451-462.

40. Balligand JL. Cardiac salvage by tweaking with beta-3-adrenergic receptors. Cardiovasc Res. 2016 Jul 15;111(2):128-33.

41. Niu X, Watts VL, Cingolani OH, Sivakumaran V, Leyton-Mange JS, Ellis $\mathrm{CL}$, Miller KL, Vandegaer K, Bedja D, Gabrielson KL, Paolocci N, Kass DA, Barouch LA. Cardioprotective effect of beta-3 adrenergic receptor agonism: role of neuronal nitric oxide synthase. J Am Coll Cardiol 2012;59:1979-1987.

42. Lim SL, Lam CS, Segers VF, Brutsaert DL, De Keulenaer GW. Cardiac endothelium-myocyte interaction: clinical opportunities for new heart failure therapies regardless of ejection fraction. Eur Heart J 2015;36:2050-2060.

43. Cernecka H, Sand C, Michel MC. The odd sibling: features of $\beta 3$ adrenoceptor pharmacology. Mol Pharmacol. 2014 Nov;86(5):479-84.

44. Bundgaard $H$, Axelsson A, Hartvig Thomsen J, Sørgaard M, Kofoed KF, Hasselbalch R, Fry NA, Valeur N, Boesgaard S, Gustafsson F, Køber L, Iversen $\mathrm{K}$, Rasmussen $\mathrm{HH}$. The first-in-man randomized trial of a beta3 adrenoceptor agonist in chronic heart failure: the BEAT-HF trial. Eur J Heart Fail. 2017 Apr;19(4):566-575.

45. Balligand JL. Cardiac beta3-adrenergic receptors in the clinical arena: the end of the beginning. Eur J Heart Fail. 2017 Apr;19(4):576-578.

46. Pouleur AC, Anker S, Brito D, Brosteanu O, Hasenclever D, Casadei B, Edelmann F, Filippatos G, Gruson D, Ikonomidis I, Lhommel R, Mahmod M, Neubauer S, Persu A, Gerber BL, Piechnik S, Pieske B, Pieske-Kraigher E, Pinto F, Ponikowski P, Senni M, Trochu JN, Van Overstraeten N, Wachter R, Balligand JL. Rationale and design of a multicentre, randomized, placebocontrolled trial of mirabegron, a Beta3-adrenergic receptor agonist on left ventricular mass and diastolic function in patients with structural heart disease Beta3-left ventricular hypertrophy (Beta3-LVH). ESC Heart Fail. 2018 Oct;5(5):830-841.

47. Shewan LG, Coats AJS, Henein MY. Authors' Responsibilities and Ethical Publishing. International Cardiovascular Forum Journal 2018;13:3-4, DOI: 10.17987/icfj.v13i0.525. 